\title{
Organization, operations, and success of environmental organized crime in Italy and India: a comparative analysis
}

(Accepted for publication on The European Journal of Criminology on Fri, Mar 11, 2016)

Author 1: Aunshul Rege

Affiliation: Temple University, US

Author 2: Anita Lavorgna

Affiliation: University of Southampton, UK

\section{Corresponding details:}

Dr Anita Lavorgna

Lecturer in Criminology

Social Sciences

University of Southampton

SO17 1BJ

07578747343

A.Lavorgna@soton.ac.uk

\begin{abstract}
Despite the devastating short- and long-term consequences of resource-related environmental crimes, rampant illegal soil and sand mining continues worldwide. In countries such as India and Italy, organized crime groups have emerged as prominent illegal suppliers of soil and sand. The proposed study focuses on an understudied research area at the intersection between organized crime and environmental crimes, and offers a trans-comparative study of illegal soil and sand mining conducted by Indian and Italian organized crime groups with two main objectives. First, a comparative analysis of the organizational mechanisms, operational practices, threat management, and supporting cultural, regulatory, and policing factors is conducted. Second, a discussion of how these groups reflect mainstream models and theories of organized crime is offered.
\end{abstract}

Keywords: environmental crime, mafia, organized crime, sand mining, comparative analysis, document analysis

\section{Introduction}

Environmental crimes, specifically resource-related crimes, include those crimes that illegally harvest the earth's natural resources, such as flora, fauna, and minerals, thereby negatively impacting the environment. One such natural resource is soil and especially sand, which can be used for manufacturing concrete, brick and glass, for water filtration, in leisure and sports industries (golf courses and football pitches), in horticulture, in everyday products such as in dried food, detergents, cosmetics, hair spray, and toothpaste, and in technology such as computers, mobile phones, and credit cards (sand.org, 2011; Dupont, 2013). An average house requires approximately 200 tons of sand, larger buildings require approximately 3,000 tons of sand, and just one kilometer of highway requires 30,000 tons of sand (Delestrac, 2013; Dupont, 2013). The global trade in sand yields 70 billion dollars every year (Dupont, 2013).

Not surprisingly, soil and sand are hot commodities and, unfortunately, existing regulated supplies are not enough to satisfy the enormous demand. To keep up with this demand, soil and 
sand are mined illegally and extensively; currently approximately 70 countries are experiencing illegal mining (Delestrac, 2013; Coastalcare.org, 2014). The problems resulting from excessive and illicit soil and sand mining include the destruction of natural beaches and the ecosystems they protect, habitat loss for globally important species, increased shoreline erosion rates, reduced protection from storms, tsunamis and wave events, and economic losses resulting from loss of coastal aesthetics and tourism (Young and Griffith, 2009).

Despite these devastating short- and long-term environmental consequences, rampant illegal soil and sand mining continues worldwide. In countries such as India and Italy, organized crime groups have emerged as prominent illegal suppliers of environmental resources that are harvested from within their respective borders. India's 'Sand Mafia' are sophisticated organized crime groups that illegally excavate and sell sand for approximately USD 16 million per month (Rege, forthcoming). In Italy, the involvement of organized crime groups in environmental crimes - so-called 'Ecomafias', - has largely attracted scholarly attention (see, among others, Massari and Monzini, 2004; Ruggiero and South, 2010; Pergolizzi, 2012; Sergi and Lavorgna, 2012; Caneppele et al., 2013; Walters, 2013; Martone, 2014; Peluso, 2015; Sergi and South, forthcoming). Ecomafias are considered active also in the illegal soil mining that occurs to meet the demand of the construction industry (Parliamentary Inquiry committee, 2000; Sciarrone, 2001; Direzione Investigativa Antimafia, 2013; Lavorgna, 2015). This activity is closely related to illegal waste disposal in order to maximize profits, for a turnover of almost USD 2 billion per month (Legambiente, 2014a): indeed, resulting holes (as well as pre-existing caves) are illegally filled with waste as dumping sites. As Nunzio Perrella, the first pentito (a former mafia member, now collaborator with justice) of Ecomafia, said in 1988 ' a munnezza è oro' ('trash is gold') (as reported in Marsala and Mura, 2009). Any type of waste can be dumped in this way, form toxic industrial waste and tires to demolition material and even nuclear waste (Parliamentary Inquiry Committee, 1997; 2012a; Massari and Monzini, 2004).

Researchers have examined the intersections of organized crime and environment crimes worldwide, such as illegal fishing (Osterblom et al., 2011; Petrossian and Clarke, 2014; Sander et al., 2014), illegal wildlife hunting and poaching (Rosen and Smith, 2010; Moreto and Lemieux, 2014; Pires, 2015), illegal harvesting and logging (Innes, 2010; Tacconi, 2012; Bader et al., 2013), and illegal hazardous waste dumping (Block and Scarpitti, 1985; Celeste and Celebrezze, 1986; Massari and Monzini, 2004; Senior and Mazza, 2004). However, the area of illicit soil and sand mining has been generally overlooked (Rege, forthcoming). Also surprising, is the relative dearth of global comparative studies that examine the intersection of organized and environmental crimes. As such, this paper offers a trans-comparative study of illegal soil and sand mining conducted by the Italy's Ecomafias and India's Sand Mafia with two main objectives. First, it provides a comparative analysis of traditional concepts of organized crime, namely structure, modus operandi, threat management strategies, and cultural, regulatory, and policing factors that impact operations. Second, it offers a theoretical discussion of how these groups reflect mainstream models and theories of organized crime.

1 Ecomafia is defined as any mafia-led criminal sector which is highly dangerous for the environment, such as unlawful building or illegal dumping of toxic waste (Fontana, 2014). Environmental crimes are generally considered high-reward low-risk activities for organized crime. The notion of 'ecomafia', which entered common parlance and even dictionaries since 1999, has received attention especially thanks to the annual report carrying this name and edited, since 1997, by the Italian environmental NGO Legambiente in collaboration with national law enforcement agencies. 
The choice of India and Italy was purposive. First, these countries serve as good choices for this comparative study as they both are infamous for environmental crimes and are experiencing similar organized crime group involvement: Italy has a sad tradition of organized crime presence, whose involvement in environmental crimes has been long established. India has been experiencing illicit sand mining for several decades, but has only recently been gaining attention in the media. The news coverage received by some environmental activists and law enforcement agents who have experienced threats and violence has made India's Sand Mafia more well-known on a global scale (Sugden, 2013; Lasseter and Katakey, 2014; Beiser, 2015; Paul, 2015). Second, both countries are infamous for corruption and the political-organized crime-law enforcement nexus. Third, this choice allowed us to take into consideration one developed country (Italy) still suffering a deep economic and financial crisis that has harshly affected also the construction sector, and a developing country (India) that is experiencing a real boom in the construction sector. Finally, both countries use the illegally mined sand for construction within their own national borders. Other countries such as Indonesia, Thailand, Vietnam and Cambodia export sand abroad (UNEP 2014), while India and Italy engage in illicit sand mining for their own respective construction sectors.

This paper is structured as follows: the next section illustrates briefly the current state of affairs in both India and Italy with regards to organized crime groups' participation in the illegal soil and sand mining arena. The third section discusses the document analysis methodology employed, possible limitations, and how these are managed. The fourth section details the comparative analysis of how the Ecomafias and Sand Mafia organize, operate, and manage threats. The fifth section offers a theoretical dialogue of how both groups align with the conventional models of organized crime and environmental crime. The paper concludes by outlining potential avenues for further research in this filed.

\section{India and Italy: venues for illegal sand mining and extraction techniques}

Organized crime groups engage in illegal soil and sand mining for the primary purpose of using it in construction sites (Direzione Investigativa Antimafia, 2013; Sugden, 2013). The yearly demand for sand in India is 23 million tons while riverbed supplies offer only 7 million tons (Kumar, 2013). The Sand Mafia emerged to fill this market demand-supply gap and its (publicly-known) operations occur in twelve states: Gujrat, Maharashtra, Karnataka, Kerala, Tamil Nadu, Andhra Pradesh, Odisha, West Bengal, Bihar, Uttarakhand, Nagaland, and Madhya Pradesh (Sambhav et al., 2012). While discrepancies exist between the various estimates in the open literature, approximately Rs. 500 crore (approximately USD 80 million) in sand are stolen every year (Keelor and Aradhak, 2013).

Similarly, in Italy, soil is a highly coveted commodity, with the yearly demand approximating 100 million tons, even if the demand is decreasing as an effect of the economic crisis that severely hit the construction sector (Legambiente, 2014b). Unfortunately, there are no reliable estimates on the amount of soil illegally mined in the country, as most research focuses on the related illegal waste dumping. According to the last Ecomafia report (Legambiente, 2014a), Ecomafia activities are concentrated in the administrative regions of southern Italy where Italian mafias originate from (Puglia, Campania, Calabria, and Sicilia), but are increasingly common also in other regions in central and northern Italy (such as Lazio, Liguria, Lombardia, Toscana, and Veneto), where organized crime is present even if in different forms (Lavorgna and Sergi, 2014). With regards to Italy, this paper mainly focuses on the involvement 
of Camorra clans in Campania and of 'ndrangheta groups in Lombardia. These groups are policrime groups involved in a wide range of criminal activities, including environmental crimes. This choice allows considering the behavior of two different but comparable groups in different parts of the country (Lavorgna and Sergi, 2014), while taking into account cases with enough coverage in media and investigative reports to be studied with sufficient depth ${ }^{2}$.

In both countries, sand and soil can be mined from either dry or wet sources. Dry sources include illegal quarries, inland dunes and beaches using drillers, stone crushers and excavators (ENVIS, 2013; Legambiente, 2014b). Wet sources include river beds, where sand is extracted through a process called dredging; sand is either scooped or sucked from the river bottoms (ENVIS, 2013; Kansasriver.org, 2014). With regards to Italy, however, there is not much evidence of soil illegally mined from wet sources, which might be explained by the fact that such a criminal activity would be more difficult to hide because of the characteristics of Italian city planning and tourist areas.

\section{Methodology}

Given that this is an exploratory, cross-cultural comparative research, qualitative document analysis is ideal for obtaining an in-depth first understanding of the phenomenon of illicit sand mining (Yin, 1994; Stake, 1995). Document analysis is a systematic procedure for reviewing or evaluating documents; data can be examined, reorganized and analyzed to gain a different level of understanding and develop new empirical knowledge (Bowen, 2009). Bearing witness to covert, illicit events, documents provide background and variety of information, which helps researchers understand the inner workings of criminal enterprises and highlight specific issues and conditions that surround the phenomena under investigation. Therefore, documents are the most effective means of gathering data when events cannot be observed, such as illegal sand mining operations, or when criminal members cannot be accessed for study.

Document analysis is an iterative and data-dependent process. As such, we first organized data along well-known organized crime concepts in the literature: (i) organizational mechanisms (organized crime models of hierarchies and/or networks), (ii) operational practices or modus operandi, (iii) threat management tactics (violence, threats, intimidation, etc), and (iv) supporting factors, such as corruption and political support, which are collectively related to the central questions of this research (Lyman and Potter, 2015). Furthermore, these categories were used in prior work on illicit sand mining in India, which made these categories a logical framework for comparative analysis (Rege, forthcoming). Thus, we conducted a first-pass review of the documents and identified meaningful and relevant passages of text as they pertained to these broad categories (Bowen, 2009). Second, we conducted a thematic analysis of our data, which

2 As documented in the recently declassified deposition of the former mafia member, then collaborator with justice Carmine Schiavone on the involvement of the Casalesi clan (i.e., the most powerful Camorra clan) in waste trafficking (Parliamentary Inquiry Committee 1997, declassified in October 2013), it is at least since the mid-1980s that sand mining and illegal waste disposal occur in Campania, leading to huge problems in an area that was traditionally praised for its beauty and natural resources (Andreatta, 2009; Sales, 2012; Ferrara et al., 2013; Past, 2013). Also Lombardia, where there is a very strong presence of affiliated to the 'ndrangheta (Varese, 2006; Lavorgna et al., 2013), proved to be permeable to serious environmental crimes, and since the 1960s it is estimated that up to 70 percent of firms operating in the earthmover and construction sectors and operating in the area are ascribable to people potentially linked to the 'ndrangheta (Parliamentary Inquiry Committee, 2012a). 
involved a careful, more focused re-reading and review of the data. Here, data was sifted using the above-listed broad categories [see Tables 1 and 2 for details]. Data for each of these categories was collected for both the Sand Mafia and Ecomafias, which allowed for a thorough comparative analysis of connections, alliances, divisions of labor, threat managing techniques, and socio-cultural facilitating factors.

We sampled documents from various sources. Keyword searches were run to identify relevant articles and reports to consider for the analysis [see Appendix A for details]. For India, we examined publicly available Indian newspaper articles (such as The Times of India; Daily News Analysis; Hindustan Times) and reports by the government (Environmental Information System) and by environmental activist agencies and magazines (Awaaz Foundation; Down To Earth; Coastal Care) that had been published between 2010 (January 1) to 2014 (September 30). This time period and data sources were chosen due to the extensive media coverage and paucity of other academic sources (specific to the Sand Mafia) respectively. As noted earlier, while India has been experiencing illegal sand mining for many years, it has only recently started getting attention in media, environmental and academic fronts. After checking for quality and redundancy, a total of 157 media news, 10 outputs from the governmental Environmental Information System, and 7 reports from environmental agencies were selected for the analysis.

With regards to Italy, a keyword search was run on the online archives of five Italian newspapers: the three major ones at the national levels (Il Corriere della Sera, La Repubblica, and La Stampa) and the two major ones at the regional level for Lombardia and Campania given that some of the news of interest might not have reached the national level (respectively $I l$ Giorno and $\mathrm{Il} \mathrm{Mattino)^{3 }}$. A total of 318 media news were selected for the analysis, most of which focusing on the related illegal waste disposal, probably because of major scandals that hit Campania in this timeframe. Apart from media news, all relevant documents published by the main environmental activist Italian agency (Legambiente, for a total of 10 dossiers and reports on soil consumption and 9 on ecomafias) as well as 8 reports from the Direzione Investigativa Antimafia (National Anti-mafia Directorate) and 15 reports from the Parliamentary special commissions on environmental crimes were retrieved online and taken into consideration. To maintain consistency with the data collection period chosen for India, documents published from 2010 (January 1) to 2014 (September 30) were considered.

The sampling strategy used was purposive and information was selected to find different manifestations of the phenomena under investigation illustrated with enough details to generate in-depth understanding (maximum variation sampling) (Patton, 1990). Documents were sampled until data began to repeat themselves and no new/additional information emerged. Collectively, these data offered in-depth insight on illicit mining operations, criminal organization, and the various techniques used by the groups to manage threats.

There are limitations with the methodology chosen. First, regarding the data gathering strategy, media news and reports are secondary sources that report may be biased and incomplete. Quantitative data in particular are difficult to ascertain and validate due to the illegal nature of the activities observed, and the existing estimates are produced by NGOs that do not always assure methodological rigor in their analyses; however, those estimates are the only ones

3 These are the major newspapers in Italy according to the data of Accreditamenti Diffusione Stampa [Press Diffusion Accreditation], retrievable from: http://www.adsnotizie.it/certif/index.php. 
available at the moment ${ }^{4}$. However, all information gathered was cross verified, corroborated, and enriched by relying on different reputable sources. Second, qualitative document analysis might raise issues of validity. It is worth noting that generalizability is a desirable goal but not the purpose of qualitative research (Corbin and Strauss, 2008), where external and internal validity is gained by being mentally replicable, analytically rigorous, and explicitly systematic (Patton, 1999: 1191). In this study we carefully followed all these requirements: we documented step by step the procedures used for data gathering and data analysis, to prevent biased interpretations we used multiple sources of data produced by stakeholders in different positions, and all data collected were manually and systematically coded consistently by both researchers.

Table 1 - Organizing data for the comparative content analysis (India)

\begin{tabular}{|c|c|c|c|c|c|c|c|c|c|}
\hline \multirow[t]{3}{*}{ Sources } & \multicolumn{9}{|c|}{ Cases/components } \\
\hline & \multirow[t]{2}{*}{ Venues } & \multirow{2}{*}{$\begin{array}{l}\text { Extraction } \\
\text { techniques }\end{array}$} & \multirow{2}{*}{$\begin{array}{l}\text { Organization } \\
\text { of operations }\end{array}$} & \multirow{2}{*}{$\begin{array}{l}\text { Operational } \\
\text { practices }\end{array}$} & \multirow[b]{2}{*}{$\begin{array}{c}\text { Violence/ } \\
\text { intimidation }\end{array}$} & \multicolumn{3}{|c|}{ Facilitators/contribution to success } & \multirow[b]{2}{*}{ Adaptation } \\
\hline & & & & & & Corruption & $\begin{array}{c}\text { Poor } \\
\text { regulation }\end{array}$ & $\begin{array}{l}\text { Local } \\
\text { support }\end{array}$ & \\
\hline \multicolumn{10}{|c|}{ National newspapers } \\
\hline $\begin{array}{l}\text { Times of } \\
\text { India }\end{array}$ & $\checkmark$ & $\checkmark$ & $\checkmark$ & $\checkmark$ & $\checkmark$ & $\checkmark$ & $\checkmark$ & $\checkmark$ & $\checkmark$ \\
\hline Daily $N$. & $\checkmark$ & & $\checkmark$ & $\checkmark$ & $\checkmark$ & $\checkmark$ & & $\checkmark$ & \\
\hline The Hindu & $\checkmark$ & & $\checkmark$ & & $\checkmark$ & $\checkmark$ & $\checkmark$ & & \\
\hline Hindus. & $\checkmark$ & & $\checkmark$ & $\checkmark$ & $\checkmark$ & $\checkmark$ & & $\checkmark$ & \\
\hline NDTV & $\checkmark$ & $\checkmark$ & $\checkmark$ & & $\checkmark$ & $\checkmark$ & $\checkmark$ & & $\checkmark$ \\
\hline Indian $E$ & $\checkmark$ & $\checkmark$ & $\checkmark$ & $\checkmark$ & $\checkmark$ & $\checkmark$ & & $\checkmark$ & \\
\hline \multicolumn{10}{|c|}{ Environmental activist groups } \\
\hline Down to $E$ & $\checkmark$ & $\checkmark$ & & $\checkmark$ & & $\checkmark$ & $\checkmark$ & & $\checkmark$ \\
\hline Costal C. & $\checkmark$ & $\checkmark$ & $\checkmark$ & $\checkmark$ & & & $\checkmark$ & & \\
\hline \multicolumn{10}{|c|}{ Governmental reports } \\
\hline $\begin{array}{l}\text { Environm. } \\
\text { Inf. System }\end{array}$ & $\checkmark$ & $\checkmark$ & $\checkmark$ & $\checkmark$ & & & $\checkmark$ & & \\
\hline
\end{tabular}

4 Furthermore, because of the lack of quantitative data on illegal soil and sand mining in both countries (both within and outside the context of organized crime), it was not possible to carry out comparative statistical analysis, relative frequencies, and the like. 
Table 2 - Organizing data for the comparative content analysis (Italy)

\begin{tabular}{|c|c|c|c|c|c|c|c|c|c|}
\hline \multirow[t]{3}{*}{ Sources } & \multicolumn{9}{|c|}{ Cases/components } \\
\hline & \multirow[t]{2}{*}{ Venues } & \multirow{2}{*}{$\begin{array}{l}\text { Extraction } \\
\text { techniques }\end{array}$} & \multirow{2}{*}{$\begin{array}{l}\text { Organization } \\
\text { of operations }\end{array}$} & \multirow{2}{*}{$\begin{array}{c}\text { Operational } \\
\text { practices }\end{array}$} & \multicolumn{5}{|c|}{ Facilitators/contribution to success } \\
\hline & & & & & $\begin{array}{l}\text { Violence/ } \\
\text { intimidation }\end{array}$ & Corruption & $\begin{array}{l}\text { Poor } \\
\text { regulation }\end{array}$ & $\begin{array}{l}\text { Local } \\
\text { support }\end{array}$ & Adaptation \\
\hline \multicolumn{10}{|c|}{ National newspapers } \\
\hline Il Corriere & $\checkmark$ & & & & $\checkmark$ & & $\checkmark$ & & \\
\hline La Repub. & $\checkmark$ & & & $\checkmark$ & $\checkmark$ & $\checkmark$ & & $\checkmark$ & \\
\hline La Stampa & $\checkmark$ & & & & $\checkmark$ & & $\checkmark$ & & \\
\hline \multicolumn{10}{|c|}{ Regional newspapers } \\
\hline Il Giorno & $\checkmark$ & & & $\checkmark$ & $\checkmark$ & $\checkmark$ & & $\checkmark$ & \\
\hline Il Mattino & $\checkmark$ & & & $\checkmark$ & $\checkmark$ & $\checkmark$ & & $\checkmark$ & \\
\hline \multicolumn{10}{|c|}{ Environmental activist groups } \\
\hline Legamb. & $\checkmark$ & $\checkmark$ & $\checkmark$ & $\checkmark$ & $\checkmark$ & $\checkmark$ & $\checkmark$ & $\checkmark$ & \\
\hline \multicolumn{10}{|c|}{ Governmental and parliamentary reports } \\
\hline $\begin{array}{l}\text { National } \\
\text { Anti-mafia }\end{array}$ & $\checkmark$ & & $\checkmark$ & $\checkmark$ & $\checkmark$ & $\checkmark$ & $\checkmark$ & & \\
\hline $\begin{array}{l}\text { Parliam. } \\
\text { Commiss. }\end{array}$ & $\checkmark$ & $\checkmark$ & $\checkmark$ & $\checkmark$ & $\checkmark$ & $\checkmark$ & $\checkmark$ & $\checkmark$ & \\
\hline
\end{tabular}

\section{Organizing illegal mining operations}

Organizing illegal mining operations in both India and Italy have some interesting overlaps, yet there are significant differences. First, illegal mining is Italy is managed by already existing organized crime groups such as the Camorra and the "ndrangheta. In India, illegal sand mining operations have been attributed to twelve (publicly known) areas in the country that are geographically dispersed and there is no evidence of any connections between these various operations (Sambhav et al., 2012). Various new groups set shop across the country and are neither connected nor operated by a single over-arching Sand Mafia. A second difference regards the nature of ties between those involved. For instance, the Ecomafias are part of existing organized crime groups that rely deeply on kinship ties, personal contacts, and other personal relationships (Parliamentary Inquiry Committee, 1997; Paoli, 2003). India's Sand Mafia's, however, does not exhibit any familial or personal ties; all connections are purely business and profit driven (Keelor and Aradhak, 2013). Another difference is that the Sand Mafia utilizes extra laborers as needed, who comprised illegal immigrants, local villagers and fisherfolk, and even child laborers (Sambhav et al., 2012; Nair, 2013). The Ecomafias organization does not indicate any such ad hoc additions that included a similar assortment of participants. Generally clans operate a direct management over the earthmover sector ('movimento terra') by means of public contracts and sub-contracts in a way that workers involved in these activities are somehow connected to the clan and under its hierarchical control (Parliamentary Inquiry Committee, 2012a). 
Despite these larger differences, there are some interesting similarities. There is both vertical and lateral organization with the overall organization of the illegal mining operations. With regards to the hierarchical component, Italy's mining operations are controlled by wellestablished organized crime groups, while India's (dispersed) Sand Mafia appears to be managed by varying combinations of existing mining companies, local contractors, and politicians (Sambhav et al., 2012). The next rung of the ladder for Ecomafias includes members from the legal economy, such as people managing legal waste disposal companies and the legitimate earthmover sector (Sciarrone, 2001; Parliamentary Inquiry Committee, 2012a;b; Gluzzi, 2013). The equivalent in India appears to be independent contractors who possess the necessary equipment to extract and transport illegally harvested sand (Sambhav et al., 2012; Keelor and Aradhak, 2013; Pandey, 2013a). Thus it seems that the contractors who are second in line for the Ecomafias could be at a similar position with the Sand Mafia's but also at the top. Also, both Ecomafias and the Sand Mafia are often involved in other illicit operations. The former in particular not only illegally mined soil, but also filled the holes with toxic wastes and the latter engaged in illegal coal and mineral mining (Pandey, 2013a; Legambiente, 2014a). Interestingly, in both Italy and India, illegal mining was done on occasion by groups that were not involved with the Ecomafias or the Sand Mafia; these independent contractors conducted their own mining operations (Parliamentary Inquiry Committee, 2012a; Pandey, 2013a; Calderoni et al., 2014).

\section{Operational practices}

Both Italian and Indian groups are involved in large scale activities and they adopt specific strategies to disguise attention from what they are doing. In Italy, Ecomafias generally work under the umbrella of bids for public contracts in the waste management and construction sectors. In order to do this, a systems of sub-contracts is created: businesses winning the bid and operating in the legal economy are forced to rely on smaller firms controlled by the clans for specific and necessary stages of the activity, such as the earthmover one, where significant manpower but little expertise is necessary (Sciarrone, 2001; Laudati, 2013). Furthermore, figureheads - trusted persons linked by kinship or business ties - are used for hiding the real ownership of the vehicles and other machineries used (Parliamentary Inquiry Committee, 2012a). In India no evidence of this has been found, suggesting that the Sand Mafia is less sophisticated in its capacity to infiltrate the legitimate system. In some cases, however, sand drilling machines are owned and controlled by leaders of major political parties (Rashid, 2013), which indicates that the criminal groups enjoy meaningful connections with the upper-world. On the other hand, expensive machinery seized during a raid imply that the Sand Mafia could easily afford top-of-the line tools also on its own (Mendonca, 2013). Sand excavation, however, can also be done without the use of much technology or skill. If on the beaches or inland, mechanical excavators can be used, and if from riverbeds, divers can fill baskets and use 'tug signals' to pull up the looted sand and fill boats (Vijapurkar, 2013). There have been instances of legitimate sand mining corporations that are also involved in illicit sand mining. These companies already have mining permits, excavating equipment, storage and transportation capacities; on occasion, they exceed their allocated mining allowances, and sell the excess to generate extra revenue (Rege, forthcoming).

Italian groups seem to rely extensively on the falsification of documents. In particular, the $\log$ books of truck drivers are systematically falsified with regard to the distance covered, as 
well as the amount and the nature of the material hauled. Moreover, cheating on the waste or the soil type (e.g., by falsifying the relevant code as identified in the European Waste Catalogue) also allows re-selling these materials as filling material in the construction sector (Parliamentary Inquiry Committee, 2012a). In India, no evidence of document falsification was found; rather numerous duplicate mining permits were issued as needed, which indicated alliances between permit issuing offices and the sand mafias (Rege, forthcoming).

Criminal groups in both countries have to successfully manage unannounced inspections, confiscation of their grainy loot, and unpleasantries with communities that are disturbed by their operations. Trying to avoid public attention, in Italy lands to be mined and then filled with waste are bought or rented, or the activities occur so covertly that land owners do not know what is going on in their properties. There is also a constant search for local farmers willing to receive in their lands contaminated soil and to cover the operation with the periodic replacement of cultivable land, for which they already have municipal authorizations (Parliamentary Inquiry Committee, 2012a). In India, trucks, boats, and canoes are used to transport sand behind the scenes. Depending on mining site locations, between 20 to 100 trucks leave illicit mining sites every day, and in some instances huge rafts are used to help sand-laden trucks across rivers to avoid official inspections (Seshacharyulu, 2013). Henchmen follow trucks in their vehicles; this chauffeuring is to alert truck drivers of possible raids by mining or policing officials (Seshacharyulu, 2013).

In both countries mining and dumping generally occur overnight and possibly for a few days only in different areas, so to avoid summoning too much attention (Parliamentary Inquiry Committee, 2012a; Pereira, 2012; Sambhav et al., 2012; Pandey 2013a,b; Seshacharyulu, 2013), and there is a constant attention to conceal-whenever possible - the criminal activity. In Italy, for instance, the mined solid filled with waste is sometimes covered by a final layer of fine soilmaybe stolen elsewhere - and trucks containing waste to be illegally dumped are covered by a layer of excavated land to circumvent the controls by police officers (Parliamentary Inquiry Committee, 2012a). In India, roads are often laid alongside embankments to exclusively transport sand and the movement of trucks is uninterrupted and often unchecked (Sambhav et al., 2012; Nair, 2013). Rows of empty trucks are parked on the sides, and drivers and laborers are found nearby discussing the day's tasks (Pandey, 2013a). One contractor explained how illicit sand mining worked: 'mining has to be done fast. You never know when the government will stop it. Instead of manual labor, we use excavators which can fill a dumper in four minutes flat' (Sambhav et al., 2012).

\section{Factors contributing to Ecomafias and Sand Mafias success}

Four main factors contributed to the two groups' success: (1) intimidation/violence; (2) policing, political, and construction corruption; (3) poor regulatory measures; (4) local support. From 2009 to 2012, more than 130 incendiary attacks and more than 70 intimidating acts with weapons and explosives were registered in Lombardia alone (Parliamentary Inquiry Committee, 2012a). Victims did not file complains out of fear of retaliation. Also, workers non-affiliated with the clans did not press charges fearing job loss. Similarly, in India, officers and villagers who challenged the Sand Mafia were suspended, transferred, threatened, physically assaulted, tortured or even murdered (Rege, forthcoming; Keelor, 2013a; Pandey, 2013b). Violent measures were also used to manage competition. In Italy, 'environmental extortion' sometimes occurred: in areas where the mafia presence was well-established, legitimate firms simply 
avoided competing with mafia-related firms as they would experience either subtle pressure (if they were lucky) or would be beaten up (Parliamentary Inquiry Committee, 2012a; Zancan, 2014). In India, violence against rivals was used to ensure dominance. In the past few years, several states experienced 'sand wars' over mining rights (Gupta, 2013). Rival groups engaged in extorting their competition during smuggling operations. In one case, for instance, one group carrying illegally mined sand was stopped by its rival demanding 'royalty' (extortion money). This confrontation became violent resulting in the death of the extortionist group (Singh, 2013).

A second factor contributing to their success is the use of corruption and strong political ties. In India, politicians who were once funded by businesses were being funded by the Sand Mafia (Aiyar, 2013). Similarly, Italian mafias have well-established ties with political power and were generally very successful to infiltrate the public sphere (Paoli, 2003; Parliamentary Inquiry Committee, 2013). Moreover, the earthmover sector was used as a source of political influence by mafias (especially in the case of the 'ndrangheta in Lombardia), that relied on a real 'army' of owner drivers ('padroncini') from their homelands Calabria as potential voters and therefore as a political leverage tool (Parliamentary Inquiry Committee, 2012a). Corruption was used both to obtain access to public bids through structural corruptive connections and in one-off cases. For instance, in his deposition Schiavone said that there was a 'price list' to deal with public administration (Parliamentary Inquiry Committee, 1997), and the Parliamentary Inquiry Committee (2012a) reported that law enforcement officers were allegedly corrupted not to control over the trucks containing mined soil and waste. In a similar vein, police officers were often bribed to let sand-laden trucks pass through checkpoints and also warned the Sand Mafia of impending raids (Nair, 2013; Keelor, 2013b; Seshacharyulu, 2013). Similarly, law enforcement officers were allegedly corrupted not to inspect the trucks containing mined soil (Parliamentary Inquiry Committee, 2012a). Corruption was also used to engage in bid rigging practices for obtaining mining permits and licenses in both countries (Parliamentary Inquiry Committee, 2012a; Rashid, 2013).

The third factor that aided illicit sand mining operations in both countries was the presence of poor regulatory measures and poor enforcement. Until recently, with the exception of waste trafficking (art.260 of the legislative decree 152/2006) and waste burning (art.265 bis of the legislative decree 152/2006 as introduced by the law 6/2014), environmental crimes in the Italian legal framework were generally not considered felonies (delitti) but only misdemeanors (reati contravvenzionali). Sanctions were fairly low, and prescription limits expired quickly (in about four years) if compared to the lengthiness of criminal processes in Italy (Parliamentary Inquiry Committee, 2012a; Legambiente, 2013). However, in May 2015 the Italian legislature approved a new law on the introduction of environmental crimes into the Criminal Code, categorizing them as felonies. The passage of the new bill is a positive step forward, but only time will tell whether its implementation will help countering resource-related crimes (Lavorgna, 2015). There are also specific legal loopholes that are exploited in the sand/waste cycle. For instance, as it emerged from law enforcement operations such as Isola (in 2008) and ReduxCaposaldo (in 2011), the possibility to obtain haulage licenses conto terzi ('on behalf of a third party') allows the clan to figure out as supplier and service provider to sub-contractors in public bins. In this way, the clan can circumvent the need for the required certificazione antimafia (certificate of non-involvement in organized crime) (Gluzzi, 2013; Søndergaard, 2013). India also faces similar regulatory problems. There are some enforcement agents, such as the mining department, which try to confront the Mafia regularly. They do not, however, have teeth as they are not equipped with enough manpower and adequate resources, resulting in sloppy, and at 
times non-existent, regulatory practices (Aiyar, 2013; Aradhak, 2013; Pandey, 2013a). As one environmental activist noted: 'all terms of licenses are routinely violated, including the amount of sand to be dredged, timings of dredging operations, and number of dredgers permitted to operate in a given area' (Ghosh et al., 2013). Existing rules also have huge loopholes. For instance, one extraction rule requires environmental clearance only in areas above five ha (EPW, 2013). Contractors easily circumvented this rule by splitting operations into areas less than the allotted amount (EPW, 2013). Furthermore, monitoring - and thereby regulating - illicit activity might not always be easy to accomplish, given the dispersed geography and the employment of manual extraction, which is not visible compared to the use of excavators and dredgers (EPW, 2013).

The fourth factor contributing to the success of the Sand Mafia and Ecomafias was that these criminal phenomena sometimes received support from within their communities and industries. Contractors and people in the construction sites under certain circumstances actively supported the modus operandi of the Ecomafias. These people were generally well-integrated in the legal economy but were not afraid to get their hands dirty in order to increase their share of profits (Parliamentary Inquiry Committee, 2012a). Similarly, the Sand Mafia got support from community members. Farmers along riverbeds were extracting sand themselves and selling to middlemen for approximately USD 96 to 144, as opposed to getting roughly USD 5 for one day's catch (Nair, 2013). This community backing made enforcement difficult as residents were complicit and thus did not file complaints (Gupta, 2013).

Another important factor that also contributed to the Sand Mafia's success was adaptation, which was often necessary to continue operations. For instance, in response to repeated raids, the criminal groups operating in a specific area remained dormant for months only to resurface later, or simply displaced their activities to another venue (Mendonca, 2013; Pandey, 2013b; TNN, 2014). Moreover, when even illegally mined sand was not enough to keep up with India's insatiable construction appetite, the Sand Mafia adapted by using illegal filtering-i.e., 'washing of sandy loam soil and selling it as sand' (Gupta, 2013). This specific aspect was not observed (or, at least, not to this extent) in relation to Italian Ecomafias. This might depend on the fact that in Italy criminal actors running illegal mining and dumping are generally embedded in well-established poli-crime groups for whom these crimes are just one of many sources of profit, and that successfully control the territory in which they operate.

\section{Theorizing Environmental Organized Crime}

The criminological literature offers several different theoretical perspectives that account for different aspects of organized crime, namely criminal structures and criminal behaviors. Moreover, in recent years a few attempts have been carried out to offer a proper theoretical framework for environmental crimes. While the purpose of this paper is to offer a comparative analysis, this section starts the dialog on how these different theoretical frameworks can be used to understand illicit sand/soil mining operations in India and Italy.

\subsection{Modelling Environmental Organized Crime}

Different approaches have been presented over the years to explain the structure of organized crime, with an increasing emphasis on network structures over hierarchies (for an overview, see Lyman and Potter, 2015). Williams (2001) offers a refined and detailed analysis of network structures, focusing on variations in leadership and key actors. 
As emerges from the previous sections, it appears that in India there are multiple, independent Mafias rather than a single one. These groups are laterally structured and typically follow Williams' (2001) directed network model. A group of 'core organizers' forms the hierarchical component of the organized crime group; it acts as a 'steering mechanism' to coordinate the network as a whole (Williams, 2001). While media reports suggest a hierarchy, it rather appears that the Sand mafias are organized around a core, which oversees the complete sand mining operation. Core members could include existing mining companies or independent contractors. These individuals often share close ties with politicians and mining regulatory officials by offering political funding and kickbacks respectively. The remaining components of the network include small-time contractors, laborers, truck drivers, and community residents who benefit from the employment opportunity, albeit illegal (Rege, forthcoming). This directed network model allows for flexible operations. On occasion, the Sand Mafias follow Williams' (2001) mesh network model, where the mafia groups are decentralized and self-organizing. This is evident from the less sophisticated sand mining operations where villagers and fishermen use their vocational tools to excavate and sell sand to other parties.

As for Italy, the clans considered in this study are all linked to the Camorra in Campania and the "ndrangheta in Lombardia. These are both mafia-type groups (respectively mafia-like organised crime ex 416-bis and migrated mafia groups according to the typology developed by Lavorgna and Sergi, 2014), and therefore large-scale, stable, and structured organizations (Paoli, 2003). If we focus on the structural elements, also the 'ndrangheta and the Camorra are best described by Williams' (2001) directed network model. Beside a managing core-linked to mafia clans and to administrative and political power-and serving as the hierarchical component of the network, there are other various components of the network to facilitate the criminal activities ${ }^{5}$. These range from small-time contractors to entrepreneurs in the waste management or construction sectors, and many of those are not part of the mafia groups. Investigations, for instance, certified business relationships between unscrupulous legal firms and the clans (Gluzzi, 2013). Also contacts with other criminal groups emerged, especially with groups from Eastern Europe helping with the vehicles used to transport the waste (Parliamentary Inquiry Committee, 2012a:167).

In the previous sections meaningful differences among Italian and Indian groups involved in resource-related crimes have been acknowledged. Indeed, under the umbrella term 'directed networks' different types of organized crime groups can co-exist, depending on differences in their social and cultural contexts. Williams himself recognized that within the directed network model we can find both highly structured and well-established groups based on enduring memberships, and more fluid and amorphous groups, with members coming in and out according to their particular needs and opportunities (Williams, 2001). Nonetheless, both case studies consistently show that classic bureaucratic and hierarchical models of organized crime are not needed to explain sophisticated crime manifestations operating serious and large-scale illegal activities as illegal mining. A hierarchical component may exist (or not), and even when it exists it could co-exist with more fluid elements of the network.

${ }^{5}$ It should be kept in mind that there are meaningful differences in the organization of Camorra clans and 'ndrangheta groups. The former are characterized by a pulviscular and fragmented nature (Turone, 2008), without a coordinating body; the latter, on the contrary, have a more rigid organization and a specific code of conduct to be followed by all affiliated (Paoli, 2003). 


\subsection{Theories of Organized Criminal Behavior}

The organized crime literature offers numerous theoretical explanations for why organized crime occurs, such as social disorganization theory, learning theory, and enterprise theory, to name a few (Lyman and Potter, 2015). Overall, enterprise theory offers the best explanation for the intersection of organized crime and environmental crimes. This theory's basic assumptions are that the illegal economy functions much like a legal one, where the laws of supply and demand, changing customer needs, and competition dictate the operations of organized crime groups (Smith, 1980). Indeed, the shortage of legally available sand due to mining regulations and limitations in India has resulted in an underground economy that is ready to provide illegally mined sand to fill the market void. Community residents also resort to illicit sand mining to quickly generate more revenue than available through their traditional livelihoods. Furthermore, the numerous and fragmented groups scattered over India, and rival groups clashing to make money on illicit sand are indicators of the competition that exists between different providers (Rege, forthcoming). In Italy, Ecomafias are considered effective economic players, offering services at a lower price than their legitimate counterparts. In both countries, crossovers from the legitimate sector, such as politicians and police, generate revenue via kickbacks and bribes respectively. Thus, all key players involved are profit-driven.

To further explain entrepreneurial behavior in organized criminals, Smith (2009) argues that organized crime takes place at the nexus between enterprise, people, and places, and offers a tripartite model focusing on their modus essendi (criminal identity), modus operandi (ways of operating) and modus vivendi ('way of living', shared alliances between illicit and licit sectors). These three modes, both individually and collectively, are relevant to understand the entrepreneurial behavior of organized criminals. Rege (forthcoming) offers a complementary approach, examining the intersection between modus operandi, modus vivendi, and modus coordināti (modes of coordinating between different alliances) to explain how India's Sand Mafias are symbiotically partnered with politicians, law enforcement, corporations and community members during the extraction, loading, transportation, and storage phases of the illegal sand mining process (Rege, forthcoming). Similarly, this approach effectively explains the robustness and resilience of Italian groups, which enjoy strong connection with the territory, and rely on an extended network of exploitable ties that provide access to specific resources and help them to extend their reach into the legal world.

\subsection{An environmental criminology perspective: the treadmill of crime}

Green criminologists Stretesky, Long, and Lynch (2014) recently debated the implications of Schnaiberg (1980)'s Treadmill Theory for criminology. This approach, based on a political economy of the relationship between economic production and ecological disorganization, can help explaining the structural causes of environmental crime. Also, coming from a radical criminological tradition, it allows criminologists to move beyond the legal definitions of environmental crimes to better explore and understand the 'grey areas' that in the field of environmental criminology - as well as in organized crime studies-are so common. This theoretical framework and its categorization between crimes of ecological additions (such as waste dumping) and of ecological withdrawal (such as soil miming) nicely fits the cases of environmental organized crime addressed in this study. Indeed, by focusing 'on the relationship between the economy and the ecology' (Stretesky et al., 2014: 147), as recently stressed by Sergi and South (forthcoming) the 'treadmill of crime' helps explain the ecological disorganization resulting from the interplay of the various actors involved - including organized crime - in profit 
driven activities impacting the environment. Also, this approach could help research on environmental (organized) crime focus more on victims and victimization (Stretesky et al., 2014: 152ff).

\section{Conclusions}

Illicit sand mining is not unique to Italy and India. Countries such as Jamaica, Nigeria, Morocco, Israel, Indonesia, Vietnam, and Malaysia all have criminal gangs that engage in daily illegal sand mining operations to churn out profits (Beiser, 2015). This uninhibited looting of the earth's natural resources has resulted in extreme environmental damage. Unfortunately, most countries seem to remain inadequate on the regulatory and enforcement front.

We employed a comparative approach by examining Italian Ecomafias and Indian Sand Mafias to initiate dialog on this international environmental crime phenomenon. By identifying similarities and differences in organizational, operational, and threat management dynamics, this article offered some insight into an under-researched connection: organized crime (and specifically 'mafia'-type organized crime) and environmental crime. Furthermore, this comparative approach was useful in assessing the explanatory power of some key theoretical approaches in the literature. We argue that despite the geographical, cultural, and economical differences between Italy and India, the large-scale activity of illicit soil and sand mining requires network structures, specifically directed network models with core organizing actors who set out tasks performed by peripheral actors. Further research is needed to determine the model's applicability and generalizability to criminal gangs operating in other countries. A more complete understanding of the organized crime models in place might help law enforcement in their investigative activities and, in a global perspective, facilitate better coordinated responses. The comparative perspective facilitates our capacity to identify strengths and weaknesses of each country's efforts in tackling these criminal phenomena.

Last but not least, findings also indicate that economic approaches to organized crime are useful in underlying the versatility of organized crime, which reacts and adapts to contingent drivers. This view, however, is not fully adequate in explaining organized forms of environmental crimes. Social relations and social embededdness (in line with Kleemans, 2013) remain extremely important in shaping organized crime modus operandi. While this aspect has been (and still is) the object of analyses in countries with a long tradition of organized crime studies such as Italy (see, among others, Paoli, 2003), further research along this path is needed in countries with a younger criminological tradition. Also, recent theoretical developments in environmental criminology could effectively integrate the organized crime literature in this respect. 


\section{References}

Aiyar, S. (2013). Between Rock, Sand and a Hard Place. The Times of India. Retrieved August 31, 2014. Online at http://blogs.timesofindia.indiatimes.com/Swaminomics/entry/between-rocksand-and-a-hard-place.

Andretta, M. (2009) Da 'Campania felix' a discarica. Le trasformazioni in Terra di Lavoro dal dopoguerra ad oggi. Meridiana 64: 87-120.

Aradhak, P. (2013) Govt agencies lack teeth to take on sand mafia in UP. The Times of India. Retrieved August 31, 2013. Online at http://articles.timesofindia.indiatimes.com/201308-04/noida/41056706_1_mining-mafia-sand-mafia-maujabad.

Bader, H.R., Hanna, C., Douglas, C., and Fox, J.D. (2013). Illegal timber exploitation and counterinsurgency operations in Kunar Province of Afghanistan: A case study describing the nexus among insurgents, criminal cartels, and communities within the forest sector. Journal of Sustainable Forestry, 32(4), pp. 329-353.

Beiser, V. (2015) The Deadly Global War for Sand. Wired. Retrieved June 1, 2015. Online at http://www.wired.com/2015/03/illegal-sand-mining/.

Block, A. \& Scarpetti, F. (1985). Poisoning for Profit: The Mafia and toxic waste in America. New York: William Morrow.

Bowen, G.A. (2009). Document analysis as a qualitative research method. Qualitative Research Journal 9(2), pp.27-40.

Calderoni, F., Favarin, S., Garofalo, L., \& Sarno, F. (2014). Counterfeiting, illegal firearms, gambling and waste management: an exploratory estimation of four criminal markets. Global Crime (online first).

Caneppele, S., Riccardi, M. \& Standridge, P. (2013). Green energy and black economy: Mafia Investments in the wind power sector in Italy. Crime, Law and Social Change 59,pp. 319-339.

Celeste, R. \& Celebrezze, A. (1986). Report of the Organized Crime consulting Committee. Retrieved January 20, 2016. Online at https://www.ncjrs.gov/pdffiles1/Digitization/108043NCJRS.pdf

Coastalcare.org. (2014). Sand Mining. Retrieved September 16, 2014. Online at http://coastalcare.org/sections/inform/sand-mining/.

Corbin, J. \& Strauss, A. (2008) Basics of Qualitative Research. Techniques and Procedures for Developing Grounded Theory. Thousand Oaks: Sage Publications.

Delestrac, D. (2013). Let's Talk About Sand? Retrieved September 16, 2014. Online at http://coastalcare.org/2013/12/lets-talk-about-sand-denis-delestrac-at-tedxbarcelona/. 
Direzione Investigativa Antimafia. (2013). Attivita' svolta e risultati conseguiti dalla Direzione Nazionale Antimafia (period gennaio-giugno 2013). Relazione del Ministro dell'Interno e del Parlamento. Rome: DIA.

Dupont, P. (2013). Zandoorlog. Retrieved September 16, 2014. Online at http://coastalcare.org/2014/03/zandoorlog/.

ENVIS (Environmetnal Information System). (2013). Sand Dredging, Sand Mining or Both? Retrieved January 20, 2014. Online at http://www.ismenvis.nic.in/Database/SANDDREDGING_MINING_3456.aspx.

EPW (Economic \& Political Weekly). (2013). Regulating Sand Mining. Economic \& Political Weekly. Retrieved December 12, 2013. Online at http://www.epw.in/editorials/regulating-sandmining.html.

Fontana, E. (2014). Ecomafias. Flare Network Dictionary. Retrieved March 1, 2013. Online at http://www.flarenetwork.org/report/dictionary/ecomafias.htm.

Ferrara, L., Iannace, M., Patelli, A.M., \& Arienzo, M. (2013). Geochemical survey of an illegal waste disposal site under a waste emergency scenario (Northwest Naples, Italy). Environmental Monitoring and Assessment 185(3), pp. 2671-2682.

Ghosh, S., Pawar, Y., \& Gidwani, D. (2013). A Sandstorm is coming: Courtesy Sand Mafia and sand mining. Daily News Analysis. Retrieved August 31, 2014. Online at http://www.dnaindia.com/mumbai/report-a-sandstorm-is-coming-courtesy-sand-mafia-and-sandmining-1869629.

Gluzzi, C. (2013). I viaggi d'oro dei Tir della mafia tra discariche e cantieri. E i veleni finiscono sotto le case. Corriere della sera. Retrieved May 10, 2014. Online athttp://milano.corriere.it/milano/notizie/cronaca/13_giugno_5/tir-ndrangheta-veleni-mafia2221491700885.shtml.

Gupta, S. (2013). High stakes, mega bucks fuel illegal 'dig-load-sell' sand business. The Times of India. Retrieved January 27, 2014. Online at http://articles.timesofindia.indiatimes.com/2013-08-11/india/41294121_1_sand-business-worthrs-crore.

Innes, J.L. (2010). Madagascar rosewood, illegal logging and the tropical timber trade. Madagascar Conservation \& Development 5(1).

Kansasriver.org. (2014). Sand and Gravel Dredging. Retrieved November 10, 2013. Online at http://kansasriver.org/protect/sand-and-gravel-dredging/.

Keelor, V. (2013a). Greater Noida locals brave bullets, chase away sand mafia. The Times of India. Retrieved January 25, 2014. Online at http://timesofindia.indiatimes.com/city/noida/ 
Greater-Noida-locals-brave-bullets-chase-away-sand-

mafia/articleshow/21562701.cms?intenttarget=no.

Keelor, V. (2013b). Sand mining causes Yamuna to shift 500 m east, threaten Noida. The Times of India. Retrieved August 31, 2013. Online at

http://articles.timesofindia.indiatimes.com/2013-08-10/noida/41266073_1_illegal-sand-dredgerssand-mining-sand-mafia.

Keelor, V. \& Aradhak, P. (2013). Durga Nagpal crackdown cost sand mafia 500 crore. The Times of India. Retrieved January 20, 2014. Online at

http://articles.timesofindia.indiatimes.com/2013-08-03/noida/41032835_1_sand-mafia-illegalsand-mining-river-sand.

Kleemans, E.R. (2013). Organized crime and the visible hand: A theoretical critique on the economic analysis of organized crime. Criminology \& Criminal Justice, 13(5), pp. 615-629.

Kumar, A. (2013). Illegal sand mining and transportation made cognizable offense. The Times of India. Retrieved January 20, 2014. Online at http://articles.timesofindia.indiatimes.com/2013-1122/bangalore/44363772_1_sand-mining-sand-blocks-river-sand.

Lavorgna, A. (2015). Dirty Business: Italy cracks down on environmental crime. Jane's Intelligence Review, June, pp.42-45.

Lavorgna, A., Lombardo, R., \& Sergi, A. (2013). Organized Crime in Three Regions: Comparing the Veneto, Liverpool, and Chicago. Trends in Organized Crime 16(3), pp. 265-285.

Lavorgna, A. \& Sergi, A. (2014). Types of organized crime in Italy. The multifaceted spectrum of Italian criminal associations and their different attitudes in the financial crisis an in the use of Internet technologies. International Journal of Law, Crime and Justice, 42(1), pp. 16-32.

Laudati, A. (2013). Capo Procura di Bari invita le imprese edili a reagire contro mafia. $L a$ Gazzetta del Mezzogiorno. Retrieved March 1, 2013. Online at http://www.lagazzettadelmezzogiorno.it/homepage/capo-procura-di-bari-invita-le-imprese-edilia-reagire-contro-mafia-no629023/.

Lasseter, T. \& Katakey, R. (2014). Inside India's Deadly Sand Mafia. Bloomberg. Retrieved January 12, 2016. Online at http://www.bloomberg.com/news/2014-12-17/indian-college-kids-asand-mafia-path-a-river-of-death.html

Legambiente. (2013). Terra dei fuochi: radiografia di un ecocidio. I numeri, le responsabilità, le conseguenze sulla salute dei cittadini e le proposte di Legambiente. Retrieved May 10, 2014. Online at http://www.legambiente.it/sites/default/files/docs/dossier_terradeifuochi_2013.pdf.

Legambiente. (2014a). Ecomafia 2014, Nomi e numeri dell'illegalità ambientale. Milan: Edizioni Ambiente. 
Legambiente. (2014b). Rapporto cave 2014, I numeri, il quadro normativo, il punto sull'impatto economico e ambientale dell'attività estrattiva nel territorio italiano. Milan: Edizioni Ambiente.

Lyman, M.D. \& Potter, G.W. (2015). Organized crime. Upper Saddle River, NJ: Prentice Hall.

Marsala, R. \& Mura, A. (2009). Il traffico dei rifiuti. AgoraVox. Online at http://www.agoravox.it/Il-traffico-dei-rifiuti.html

Martone, V. (2014). State, market, and mafias: political-criminal networks and local governance in the Campania region. The European Review of Organised Crime, 1(2), pp. 57-80.

Massari, M. \& Monzini, P. (2004). Dirty Businesses in Italy: A Case-study of Illegal Trafficking in Hazardous Waste. Global Crime, 6(3-4), pp. 285-304.

Mendonca, G. (2013). Illegal sand dredging in Panvel busted. The Times of India. Retrieved January 25, 2014. Online at http://timesofindia.indiatimes.com/city/navi-mumbai/Illegal-sanddredging-in-Panvel-busted/articleshow/23929461.cms.

Moreto, W.D. \& Lemieux, A.M. (2014). From CRAVED to CAPTURED: Introducing a Product-Based Framework to Examine Illegal Wildlife Markets. European Journal on Criminal Policy and Research (321), pp. 303-320.

Nair, S. (2013). Sand-mining banned in Maharashtra but flourishes on Mumbai's outskirts. The Times of India. Retrieved January 25, 2014. Online at http://articles.timesofindia.indiatimes.com/2013-08-09/mumbai/41236856_1_suction-pumpsillegal-sand-mining-sand-excavation.

Osterblom, H., Constable, A., \& Fukumi, S. (2011). Illegal fishing and the organized crime analogy. Trends in ecology \& evolution, 26(6), pp. 261-262.

Pandey, D. (2013a). Mafia mining riches from sand in Noida. The Hindu. Retrieved August 31, 2013. Online at http://www.thehindu.com/news/cities/Delhi/mafia-mining-riches-from-san/.

Pandey, D. (2013b). Police action sends sand mafia underground. The Hindu. Retrieved August 30, 2013. Online at http://www.thehindu.com/news/cities/Delhi/police-action-sends-sand-mafiaunderground/article5002839.ece.

Paoli, L. (2003). Mafia Brotherhoods: Organized Crime, Italian Style. Oxford: Oxford University Press.

Parliamentary Inquiry Committee. (1997). Commissione parlamentare d'inchiesta sul ciclo dei rifiuti e sulle attività illecite ad esso connesse. Parte segreta. Audizione del collaboratore di giustizia Carmine Schiavone, under the Presidency of. Massimo Scalia. $7^{\text {Th }}$ October 1997, declassified on $31^{\text {st }}$ October 2013. Online at http://leg13.camera.it/_bicamerali/rifiuti/resoconti/Documento_unificato.pdf. 
Parliamentary Inquiry Committee. (2000). Commissione parlamentare d'inchiesta sul ciclo dei rifiuti e sulle attività illecite ad esso connesse. Documento sui traffici illeciti e le ecomafie, under the Presidency of Massimo Scalia. 25th October 2000. Online at http://legislature.camera.it/_dati/leg13/lavori/doc/xxiii/047/d000r.htm

Parliamentary Inquiry Committee. (2012a). Relazione territoriale sulle attività illecite connesse al ciclo dei rifiuti nella regione Lombardia. Speakers: Sen.Gennaro Coronella and Sen.Daniela Mazzucconi. Commissione parlamentare di inchiesta sulle attività illecite connesse al ciclo dei rifiuti. Camera dei Deputati, Senato della Repubblica, XVI Legislatura. 12 ${ }^{\text {Th }}$ December 2012. Online at http://documenti.camera.it/_dati/leg16/lavori/ documentiparlamentari/indiceetesti/023/013/INTERO.pdf.

Parliamentary Inquiry Committee. (2012b). Commissione parlamentare d'inchiesta sul ciclo dei rifiuti e sulle attività illecite ad esso connesse. Relazione sulle bonifiche dei siti contaminati in Italia. Speakers: Sen. Dorina Bianchi and Sen. Daniela Mazzuconi. 12th December 2012. Online at http://legislature.camera.it/_dati/leg16/lavori/documentiparlamentari/indiceetesti /023/014/pdfel.htm

Parliamentary Inquiry Committee. (2013). Relazione territoriale sulle attività illecite connesse al ciclo dei rifiuti nella regione Lombardia. Speakers: On. Stefano Graziano and Sen. Salvatore Piscitelli. Commissione parlamentare di inchiesta sulle attività illecite connesse al ciclo dei rifiuti. Camera dei Deputati, Senato della Repubblica, XVI Legislatura, 5th February 2013. Online at http://www.camera.it/_dati/leg16/lavori/ documentiparlamentari/indiceetesti/023/019/INTERO.pdf.

Past, E. (2012). 'Trash Is Gold': Documenting the Ecomafia and Campania's Waste Crisis. Interdisciplinary Studies in Literature and Environment 20(3), pp. 597-621.

Patton, M. (1990). Qualitative evaluation and research methods. Beverly Hills, CA: Sage.

Patton, M. (1999). Enhancing the quality and credibility of qualitative analysis. Health Serv Res., 34(5) Pt 2, pp. 1189-1208.

Paul, S. (2015). How India's 'Sand Mafia' Pillages Land, Terrorizes People, and Gets Away With It. Vice News. Retrieved January 10, 2016. Online at https://news.vice.com/article/howindias-sand-mafia-pillages-land-terrorizes-people-and-gets-away-with-it

Peluso, P. (2015). Dalla terra dei fuochi alle terre avvelenate: lo smaltimento illecito dei rifiuti in Italia. Rivista di Criminologia, Vittimologia e Sicurezza 9(2), pp. 13-30.

Pereira, K. (2012). Sand mining: The High Volume - Low Value Paradox. Coastal care. Retrieved November 20, 2013. Online at http://coastalcare.org/2012/10/sand-mining-the-highvolume-low-value-paradox/.

Pergolizzi, A. (2012). Toxicitaly. Ecomafie e capitalismo: gli affari sporchi all'ombra del progresso. Rome: Castelvecchi. 
Petrossian, G.A. \& Clarke, R.V. (2014). Explaining and controlling illegal commercial fishing an application of the CRAVED theft model. British Journal of Criminology, 54(1), pp. 73-90.

Pires, S. F. (2015). Introduction: Wildlife Crime. European Journal on Criminal Policy and Research, 21(3), pp. 299-302.

Rashid, O. (2013). Mafia's role in sand mining in UP' The Hindu. Retrieved August 31, 2013. Online at www.thehindu.com/news/national/other-states/mafias-role-in-sand-mining-inup/article4992599.ece.

Rege, A. (forthcoming). Not biting the dust: using a tripartite model of organized crime to examine India's Sand Mafia. International Journal of Comparative and Applied Criminal Justice DOI:10.1080/01924036.2015.1082486

Rosen, G. E. \& Smith, K. F. (2010). Summarizing the evidence on the international trade in illegal wildlife. EcoHealth, 7(1), pp. 24-32.

Ruggiero, V. \& South, N. (2010). Green criminology and dirty collar crime. Critical Criminology, 18, pp. 251-262.

Sales, S. (2012). La questione rifiuti e la Camorra. Meridiana, 73(74), pp. 63-79.

Sambhav, K., Chakravartty, A., Suchitra, M., \& Aghor, A. (2012). Sand slips. Retrieved January 20, 2012. Online at http://www.downtoearth.org.in/content/sand-slips.

Sand.org. (2011). What is Industrial Sand? Retrieved September 16, 2014. Online at http://www.sand.org/What-is-Industrial-Sand.

Sander, K., Lee, J., Hickey, V., Mosoti, V.B., Virdin, J., \& Magrath, W.B. (2014). Conceptualizing maritime environmental and natural resources law enforcement-The case of illegal fishing. Environmental Development, 11, pp. 112-122.

Schnaiberg, A. (1980). The Environment: from Surplus to Scarcity. New York: Oxford University Press.

Sciarrone, R. (2001). E la mafia, starà a guardare? Il rischio criminalità. Meridiana, 41, pp. 165185.

Senior, K. \& Mazza, A. (2004). Italian 'Triangle of death' linked to waste crisis. The lancet oncology, 5(9), pp. 525-527.

Sergi, A. \& Lavorgna, A. (2012). Trade secrets: Italian mafia expands its illicit business. Jane's Intelligence Review, September, pp. 44-47.

Sergi, A. \& South, N. (forthcoming) Earth, Water, Air, Fire. Environmental Crimes, Mafia Power and Political Negligence in Calabria. In Antonopolous G (ed.) Illegal Entrepreneurship, 
'Organised Crime' and Social Control: Essays in Honour of Professor Dick Hobbs, Netherlands: Springer.

Seshacharyulu, A. (2013). Night life on Krishna river high with sand mining' Indian Express. Retrieved November 20, 2013. Online at http://www.newindianexpress.com/states/andhra pradesh/Night-life-on-Krishna-river-high-with-sand-mining/2013/11/18/article1896842.ece.

Singh, P. (2103). Sand mafia clash claims life in Macchiwara. Hinduastan Times. Retrieved August 31, 2013. Online at http://www.hindustantimes.com/punjab/chandigarh/sand-mafiaclash-claims-life-in-machhiwara/article1-1102163.aspx.

Smith, D.C. (1980). Paragons, pariahs, and pirates. A spectrum-based theory of enterprise. Crime and Delinquency, 26(3), pp. 358-386.

Smith, R. (2009). Understanding entrepreneurial behavior in organized criminals. Journal of Enterprising Communities: People and Places in the Global Economy, 3(3), pp. 256-268.

Søndergaard, S.B. (2013). The European Union Solidarity Fund's response to the 2009 Abruzzi earthquake: The relevance and cost of the operations. Working Document on Special Report No 24/2012. Retrieved May 10, 2014. Online at http://www.europarl. europa.eu/meetdocs/2009_2014/documents/cont/dt/1007/1007699/1007699en.pdf.

Stake, R.E. (1995). The art of case study research. Thousand Oaks, CA: Sage.

Stretesky, P.B., Long, M.A. \& Lynch, M. (2014). The Treadmill of Crime. New York: Routledge.

Sugden, J. (2013). Why India Has a 'Sand Mafia'. The Wall Street Journal. Retrieved August 28, 2013. Online at http://blogs.wsj.com/indiarealtime/2013/08/06/why-india-has-a-sand-mafia/.

Tacconi, L. (2012). Illegal logging: law enforcement, livelihoods and the timber trade. Earthscan.

TNN. (2014). Residents demand closure of illegal stone quarry in area. The Times of India. Retrieved January 20, 2014. Online at http://articles.timesofindia.indiatimes.com/2014-0114/coimbatore/46184710_1_stone-quarry-residents-demand-closure-sand.

Turone, G. (2008). Il delitto di associazione mafiosa. Giuffrè, Milano.

UNEP (United Nations Environment Programme). (2014). Sand, rarer than one thinks. Retrieved January 12, 2016. Online at http://www.unep.org/pdf/UNEP_GEAS_March_2014.pdf Varese F (2006) How Mafias Migrate: The Case of the 'Ndrangheta in Northern Italy. Law \& Society Review 40:411-444.

Vijapurkar, M. (2013). Will Durga Nagpal spur action against India's sand mafia? First Post 
India. Retrieved August 31, 2013. Online at http://www.firstpost.com/india/will-durga-nagpalcase-spur-action-against-indias-sand-mafia-1010033.html.

Walters, R. (2013). Eco mafia and environmental crime. In $\mathrm{K}$ Carrington, MJ Ball, E O'Brien,and JM Tauri (eds.) Crime, Justice and Social Democracy. London: Palgrave MacMillan, pp. 281-294.

Williams, P. (2001). Transnational criminal networks. In J Arquilla and D Ronfeldt (eds) Networks and netwars: the future of terror, crime and militancy, Santa Monica: RAND.

Yin, R.K. (1994). Case study research: Design and methods (2nd ed.). Thousand Oaks, CA: Sage.

Young, R. \& Griffith, A. (2009). Documenting the global impacts of beach sand mining. Retrieved September 16, 2014. Online at http://coastalcare.org//wp-content/pdf/egu-2009.pdf.

Zancan, N. (2014). Terra dei Fuochi, morto il vigile che lottava contro i veleni della Camorra. $L a$ Stampa. Retrieved May 10, 2014. Online at http://www.lastampa.it/2014/01/19/ italia/cronache/lottavo-da-solo-contro-i-veleni-ora-combatto-due-tumori dlR59oor6PkmZG1urnluCJ/pagina.html. 